\title{
The Characteristic of Social Danger of Offence in Scientific and Legislative Definitions in the Member Countries of the Commonwealth of Independent States and European Countries
}

\author{
Dmitry Anatolyevich Lipinsky \\ Doctor of Legal Sciences, Professor, Togliatti State University, Russia \\ E-mail:dmitri8@yandex.ru \\ Aleksandra Anatolyevna Musatkina \\ Candidate of Legal Sciences, Associate Professor, Togliatti State University, Russia \\ E-mail: Musatkinaaa@mail.ru
}

Doi:10.5901/mjss.2015.v6n3p613

Abstract

The purpose of the study is to substantiate that all types of offence and not only crimes have social danger. The achievement of this purpose should facilitate the normal functioning of the regime of legality and the legal order. Moreover, it will help the law enforcer not to bring to responsibility the offender whose actions only formally fall within the characteristics of corpus delicti and do not have social danger, which in its turn is consistant with the concept of a law-governed sate, fair law and fair justice. The obtained results will be useful for judges, prosecutors, students of law schools, legal practitioners. To achieve this purpose the following methods will be used: dialectical, comparative legal, formal legal. The use of the dialectical method allows to study the phenomenon in its complexity and interconnection with the practice and its development in social relations. The comparative legal method allows to go beyond the framework of the Russian Federation's legal system, to compare legislative definitions of offense in different countries and to identify their common features. The use of these methods has been tested by science and practice, which indicates their effective applicability to legal studies. To achieve this goal the article examines the social danger and its characteristics based on legislative definitions of an offence in different countries. It offers a comparative and legislative analysis of the concept of "offence" based on regulatory legal acts of different countries. The authors assert that all offences are not only crimes possess characteristics of social danger. A conclusion is made that a punishment which exceeds a criminal punishment cannot be imposed if an offence does not involve social danger. To a certain extent, we can judge about the nature and degree of social danger by the type of sanctions and the amount of adverse abridgment of rights that shall be imposed on the entity that has violated the legal norm. Social danger is a universal characteristic of an offence. Being a phenomenon of the real world, it does not depend on the legislation of a particular country nor on the type of its legal system. On the other hand, fixation of social danger in the law text depends on a legislator's will. Working out of a universal approach to social danger allows to avoid law enforcement mistakes, violations of human rights and freedoms, as well as facilitates integration of legal systems and the establishment of a law-governed state.

Keywords: criminal offence; social danger; harm; causing of harm; illegality; characteristics of the offence

\section{Introduction}

The question whether all offenses without exception present social danger has been under discussion in the legal literature for decades. Some experts do not mark out social danger as a distinctive feature or equate it to the concept of social maleficence. For example, V.I. Smirnov (1998) writes "Social danger is an essential characteristic of a criminal offense and cannot be acknowledged as a characteristic of other offenses" (p. 5). According to V.V. Maltsev (1986) "social danger is a characteristic of any offense (infringement)" (p. 5). A well-known theorist of law S.S. Alexeyev (1982) said that "in terms of the nature of social danger (maleficence) offenses can be subdivided into crimes and misdemeanors (administrative, disciplinary and civil)" (p. 4).

It is noteworthy that the dispute about the social danger as a characteristic of an offense as debatable not only in Russian but also in international literature. I.G. Carvell and E. Swinfen Green (1970) give a formal definition of a crime suggesting that "a good working definition of the crime is the one that presents a crime as an act or dereliction that is banned by law under threat of punishment" (p. 31). I.L. Baton (1979) supports formal and material definition of the crime. He notes that "crime is an act or dereliction, or course of conduct that are considered illegal and dangerous for society as 
a whole ... prohibited by law and deserving a punishment" (p. 13). According to C. Beccaria (1939) "the only true measure of crimes is the harm that they bring to the nation" (p. 223).

Of all legal definitions of offenses, only the Criminal Code of the Russian Federation mentions the characteristic of a social danger. Art. 14 of the Criminal Code provides the following: "A socially dangerous act, committed with guilt and prohibited by this Code under threat of punishment, shall be deemed to be a crime". In the Tax Code a tax offense is defined as "an unlawful (in violation of tax legislation) act (action or inaction) of a taxpayer, tax agent or other persons entailing liability under the present Code" (art. 106). According to the Code of Administrative Offences of The Russian Federation "a wrongful, guilty action (omission) of a natural person or legal entity which is administratively punishable under this Code or the laws on administrative offences of subjects of the Russian Federation shall be regarded as an administrative offence" (Art. 2.1). The fact that some legislative definitions of offenses fail to point out the characteristic of a social danger does not mean that offenses do not present a social danger.

\section{Research part and application of comparative law methods}

It should be noted that the legislative systems of various countries of the world are not unanimous in their definitions of social danger as a distinctive feature of the term "crime". In the former Soviet Union countries characteristic "social danger" refers in legislation to the terms "crime". For example, the Penal Code of the Republic of Belarus (2003) provides that "a socially dangerous act (action or omission), committed with guilt, specified by the present Code and prohibited by it under threat of punishment, shall be deemed to be a crime" (art. 11). Almost a similar phrasing is presented in the Criminal Code of the Republic of Tajikistan (2001) (p. 223). The Criminal Code of the Republic of Lithuania (2003) formulates not the concept of social danger, but the concept of "danger" (art. 12). Similarly, the Criminal Code of Lithuania (2003) classifies all offenses into misdemeanors and crimes, but a characteristic of social danger is specified both in the definition of a crime as well as in the definition of a criminal misdemeanor. The Criminal Code of the Republic of Moldova (2003) uses a related concept of a "prejudicial act" (art. 23).

Similarly, this issue is resolved in the legislation of the former socialist countries. For example, the Code of Criminal Procedure of the Republic of Poland (2001) states that "a prohibited act that constitutes an insignificant social danger shall not be deemed as a crime" (p. 47). According to the Criminal Code of Bulgaria (2002) "crime shall be an act dangerous to society (action or inaction), which has been culpably committed and which has been declared punishable by law" (art. 9). Furthermore the Criminal Code of Bulgaria (2002) defines the concept of "social danger". Art. 10 provides that "dangerous to society shall be an act which threatens or harms the person, the rights of the citizens, the property, the legal order established by the Constitution in the Republic of Bulgaria or other interests, protected by the legal system" ( $p$. 131).

In accordance with well-established traditions, the characteristic of social danger is not stated in the legislative formulations of the concept of "crime" in some European countries. Thus, in Section 12 of the Criminal Code of the Federal Republic of Germany (2002) it is emphasized that "felonies are unlawful acts punishable by a minimum of sentence of one year's imprisonment" (p. 125). According to Art. 10 of Criminal Code of the Swiss Confederation (2002) "felonies are offences that carry a custodial sentence of more than three years. Misdemeanours are offences that carry a custodial sentence not exceeding three years or a monetary penalty" (p. 75). In criminal laws of these countries a formal definition of the concept of "crime" is provided.

In criminal legislation of France there is no legal definition of the concept of "crime" at all. Thus, the Criminal Code of the French Republic (2002) introduces a new criterion for differentiation of criminal acts for their classification, that is the seriousness of criminal offence. In accordance with Art. 111-1, "criminal offences are categorised as according to their seriousness as felonies, misdemeanours or petty offences" (p. 67). According to Art. 111-3 "No one may be punished for a felony or for a misdemeanour whose ingredients are not defined by statute, nor for a petty offence whose ingredients are not defined by a regulation. No one may be punished by a penalty which is not provided for by the statute, if the offence is a felony or a misdemeanour, or by a regulation, if the offence is a petty offence" (p. 68). In fact, according to French Criminal Code the concept of crime follows from Art. 111-3.

Characteristics of the offence threat to society are considered dubiously in specialized legal literature as well. Experts in the field of administrative and financial law answer this question in a different way. A.V. Kurakin, A.V. Drozdov and A.V. Zubach (2001) believe that "an essential feature of an offence, which is characteristic of an administrative offence, is its social danger" (p. 3). Yu. N. Beloshapko (2001) does not single out a characteristic of social danger in the concept of a financial offence (p. 134). 


\subsection{Dialectical part. From general to specialized research and its analysis}

N.A. Gromov and S.A. Polunina (1998) include harmfulness to society into the concept of a criminal procedure offence ( $p$. 40), while according to S.G. Olkov (1994), criminal procedure offences represent social danger (p. 15).

Researchers specializing in civil law deny the characteristic of social danger in civil offences (Slesarev, 1980, p. 7). L.A. Syrovatskaya (1990) believes that a disciplinary offence does not represent social (p. 40). S.A. Shushpanov (2002) refers social danger, wrongfulness, guiltiness, and disciplinary punishability to the characteristics of an official misdemeanor (p. 16). Defining the concept of a constitutional delict, V.A. Vinogradov (2002) does not include the social danger characteristic in it (p. 27).

Thus, debates about the social danger issue as the characteristic of an offence are conducted both in the general theoretical literature and in the special literature.

\subsection{Comparison of characteristics of different types of offences}

We believe that all offences represent social danger. If an act does not represent social danger, i.e. it does not inflict harm on social relations and does not put it at threat of inflict harm, it cannot be regarded as an offence. It is a mistake to think that only crimes represent social danger. A crime differs from other offences in the extent of social danger. For instance, the Criminal Code of the Russian Federation provides for a liability for evasion of customs duties. However, there is a criminal liability for this crime only in case of a large-scale evasion. If an evasion was not of a large-scale character, it means that there is no corpus delicti in the actions of an individual or a legal entity, but there are formal elements of an administrative offence. However, an administrative offence also represents social danger, as there is a possibility of exemption from liability in case of a minor administrative offence. It is enshrined in Art. 2.9. of the Code of Administrative Offences of the Russian Federation that "where an administrative offence is insignificant, a judge, or a body, or an official authorized to resolve a case concerning the administrative offence, may relieve the person, who has committed the administrative offence, of administrative responsibility and limit themselves to a reprimand". The possibility of exemption from administrative liability emphasizes the presence of social danger in administrative offences, as in case of its absence (minor character of the offence), the person is exempt from the administrative offence. It is the extent of social danger that differs a crime from other offences, but the threat is present in all types of offences. Thus, V.M. Vedyakhin and A.F. Galuzin (1996) correctly point out that criminal contraband differs from a similar customs offence also in the extent of social danger (p. 4).

There is another conclusion in favor of the fact that not only crimes, but also all offences are characterized by social danger. For many types of offences there are liabilities that are more severe in their consequences than for some types of crimes. Thus, there is a quite clear limit for property fines in the Criminal Code of the Russian Federation. The upper limit is equal to one million rubles. In case a civil offence is committed, reimbursement of damages is limited to the size of the damages. A fine of ten thousand rubles is provided for the violation of the submission period for filing an application for the registration with a tax authority for the period of more than 90 days, whereas the minimum criminal fine is two thousand fifty rubles.

\section{Conclusion and Results}

A punishment that exceeds a criminal penalty by its size may not be imposed for an offence that does not represent social danger. To a certain extent, we can judge about the character and the extent of social danger based on the type of the sanction that determines the scope of unfavorable limitation of rights that the subject who infringed a legal norm has to endure.

Social danger is a universal characteristic of an offence. Being a phenomenon of the real world, it does not depend on the legislation of a particular country nor on the type of its legal system. On the other hand, fixation of social danger in the law text depends on a legislator's will. Working out of a universal approach to social danger allows to avoid law enforcement mistakes, violations of human rights and freedoms, as well as facilitates integration of legal systems and the establishment of a law-governed state.

\section{References}

Alekseev, S.S. (1982). General theory of law. Vol. 2. Moscow: Juridicheskaya literature (Legan Literature).

Baton, Ingraham L. (1979). Political Crime in Europe. A comparative study of France, Germany and England. Berkeley, CA: University of 
California Press. 1979.

Bekkaria, C. (1939). About crimes and punishments. Moscow: Jurisdat.

Beloshapko, Yu. N. (2001). Offence and liability in financial law. Pravovedenie (5).

Carvell, I.G. \& Green, E. swinfen Green (1970). Criminal Law and Procedure. London: Sweet \& Maxwell Limited.

Criminal Code of the Federal Republic of Germany (2002). St. Petersburg: Juridicheskij Centr Press.

Criminal Code of the French Republic (2002). St. Petersburg: Juridicheskij Centr Press.

Criminal Code of the Republic of Belarus (2003). St. Petersburg: Juridicheskij Centr Press.

Criminal Code of the Republic of Bulgaria (2002). St. Petersburg: Juridicheskij Centr Press.

Criminal Code of the Republic of Moldova (2003). St. Petersburg: Juridicheskij Centr Press.

Criminal Code of the Republic of Poland (2001). St. Petersburg: Juridicheskij Centr Press.

Criminal Code of the Republic of Tajikistan (2001). St. Petersburg: Juridicheskij Centr Press.

Criminal Code of the Swiss Confederation (2002). St. Petersburg: Juridicheskij Centr Press.

Criminal Code the Republic of Lithuania (2003). St. Petersburg: Juridicheskij Centr Press.

Gromov, N.A. \& Polunina, S.A. (1998). Sanctions in the law of criminal procedure of Russia. M.: Gorodets.

Kurakin, A.V.; Drozdov, A.V.; Zubach, A.V. and others (2001). Qualification of administrative offences. Moscow: Academy of the Ministry of Internal Affairs of Russia.

Maltsev, V.V. (1986). Investigator's assessment of social danger that infringement poses to society. Volgograd: Higher School of Investigations of the USSR Ministry of Internal Affairs.

Olkov, S.G. (1994). Criminal procedure offences in Russian legal proceedings: Abstract of a thesis ... candidate of legal sciences. Moscow.

Shushpanov, S.A. (2002). Official misconduct as the reason for disciplinary liability of a government official: Abstract of a thesis ... candidate of legal sciences. Saratov.

Slesarev, V.A.(1980). The object and result of a civil offence. Tomsk: Tomsk State University Publishing.

Smirnov, V.I. (1998). Revisiting the issue of the essence of a criminal act (a critical sketch). Kharkov.

Syrovatskaya, L.A. (1990). Liability for infringement of labor law. Moscow: Juridicheskaja literatura.

Vedyakhin, V.M. \& Galuzin, A.F. (1996). Market economy and criminal offences. Atrium: Interuniversity collection of research articles. Series "Jurisprudence". Issue 4. Togliatti: MABiBD Publishing.

Vinogradov, V.A. (2002). Constitutional responsibility: questions of theory and legal regulation. Moscow. 